\title{
Experiences and needs of patients with lower limb amputation in Saudi Arabia: a qualitative study
}

Noura Abouammoh, ${ }^{1}$ Wassim Aldebeya ${ }^{2}$ and Rabab Abuzaid ${ }^{3}$

${ }^{1}$ Department of Family and Community Medicine, College of Medicine, King Saud University, Riyadh, Saudi Arabia (Correspondence to: N. Abouammoh: nabouammoh@ksu.edu.sa). ${ }^{2}$ Department of Orthopaedic Surgery, College of Medicine, King Saud University, Riyadh, Saudi Arabia. ${ }^{3 R e h a b i l i t a t i o n}$ Centre, Surgical and Amputee, Sultan Bin Abdulaziz Humanitarian City, Riyadh, Saudi Arabia.

\begin{abstract}
Background: The effect of amputation on the social and psychological well-being of patients has been established. However, the experiences and needs of amputees for the process of adjustment varies among individuals and cultures.

Aims: This study aimed to explore the experiences and needs of lower limb amputees for social and psychological adjustment in Saudi Arabia, according to their own perspective.

Methods: Thirteen patients with lower limb amputation (mean age 47 years) were recruited from a large rehabilitation centre in Saudi Arabia for participation in interviews. A focus group discussion with 6 amputees was followed by individual, semistructured interviews with 8 amputees (which included 1 from the focus group) between November 2017 and March 2018.

Results: Patients' needs and reactions prior to and after amputation were controlled by the surrounding support system. Hopelessness and depression, body image distress, religious attitude, and family and community support all contributed to shape the overall patient experience, including psychological and physical adjustment.

Conclusions: Facilitating the re-integration of patients with lower limb amputation patients into their communities, as well as providing the required support system, is crucial to ensure a healthy adjustment process for amputees.

Keywords: lower limb amputation, patient experiences, patient needs, Saudi Arabia

Citation: Abouammoh N; Aldebeyan W; Abuzaid R. Experiences and needs of patients with lower limb amputation in Saudi Arabia: a qualitative study. East Mediterr Health J. 2021;27(4):407-413. https://doi.org/10.26719/emhj.20.124

Received: 30/09/19; accepted: 29/04/20

Copyright $\odot$ C World Health Organization (WHO) 2021. Open Access. Some rights reserved. This work is available under the CC BY-NC-SA 3.0 IGO license (https://creativecommons.org/licenses/by-nc-sa/3.0/igo)
\end{abstract}

\section{Introduction}

Amputation is a treatment of choice in several health conditions. Many factors shape a patient's psychological reaction to amputation, including age, type and level of amputation, time since amputation, social support, and active coping mechanisms (1-3).

Most patients who experience limb amputation encounter a series of multifaceted psychological responses (1). Depression is a common psychological reaction among amputees that may linger for 10-20 years after amputation and negatively affect an amputee's attempt to adjust socially and psychologically with their physical situation. (3-5). Amputees experience devastation and distress, as well as occasional denial, shortly after amputation (6-8). Poor social support and self-image are some of the main concerns that prevent a healthy coping experience (6).

Experiences and needs before and after amputation, among amputees from Arabic and Islamic cultures have not been previously studied. Culture plays an important role in shaping an individual's lifestyle, beliefs and attitudes, as well as their family and social network (9). In Saudi Arabia, 3745 cases of amputation were reported from medical rehabilitation centres and departments in 2018 (10). More than half of these cases were due to diabetes, and other causes included road traffic accidents, other accidents and malignancies. Two thirds of amputees do not receive rehabilitation services, for unreported reasons (11). The economic impact of treating amputees is burdensome, and not meeting their needs may add to its consequences (12).

The aim of the current study was to explore the adjustment experiences of amputees in Saudi Arabia and their needs before and after amputation.

\section{Methods}

\section{Study design}

This was a phenomenological study of the lived experiences of lower limb amputees within their community. The researchers had an etic perspective; looking at participants' experiences without preconceptions. Two authors (WA and RA) work in close contact with amputees, which made them more familiar with the expressions, sentiments and ways to establish rapport with the participants. 


\section{Study setting}

The study was conducted at Sultan Bin Abdulaziz Humanitarian City (SBAHC); a major nonprofit rehabilitation hospital and medical centre in Riyadh. Patients at this hospital are required to pay for services, but many receive government support to cover treatment and rehabilitation expenses.

\section{Sampling and recruitment}

This study was approved by the Institutional Review Board of SBAHC (013/2017/23, August 2017). A focus group discussion was followed by semistructured interviews with lower limb amputees from SBAHC between November 2017 and March 2018. Participants for the focus group were conveniently chosen from the Inpatient Rehabilitation Unit. From the 11 participants who were eligible, 6 attended at the time of the focus group, including 1 amputee who works at the centre.

A convenience sample of 3 inpatients and a purposive sample of 4 more patients were invited to participate in the semistructured interviews. Interviews were conducted and analysed 4 weeks after the discussion. Patients were included if they were Saudi nationals aged $\geq 18$ years. We included individuals of both sexes and with different levels of education, as well as with various times since and levels of amputation. Individuals were not chosen if they lacked the capacity to provide informed consent or had severe mental illness.

\section{Data collection}

The focus group discussion took place in a quiet meeting room at SBAHC and lasted 1 hour. Three interviews took place in the same room and the others were conducted in the patient's room and lasted 30-45 minutes. Data collection was conducted by NA in the presence of RA or WA. The topic guide was developed based on guidelines previously used in similar studies $(6,7,9,13)$ and amended according to the aim of this project (Table 1). Semistruc-

\section{Table 1 Topic guide for focus group discussion}

What does the word amputee mean to you?

What was the story behind your limb amputation?

What was your main concern before amputation? (probe: concerns about self-image, social functioning and physical func tioning)

How was your life before being an amputee? How did it change after? (psychological, social and religious)

Can you identify some of the challenges faced by lower-limb amputees? (challenges on accepting self-image, social challenges, physical challenges and psychological challenges)

What are the strategies you took (are taking) to adapt to your life after amputation? (probe: rehabilitation support including prosthesis, family and friends, talking to other amputees, spiritual support, and psychological counselling)

What do you think amputees want from the community?

What do you think professionals and community could do to facilitate integration of new amputees back into the community? Is there anything else you would like to add? tured interviews were used to handle sensitive issues (e.g., feelings and spiritual attitudes). Triangulation of data collection techniques, probing questions, more than one coder, and transparency in reporting the results were used to ensure trustworthiness of the findings.

\section{Data analysis}

All interviews were audio-recorded, transcribed verbatim, and analysed in their original Arabic language. Thematic analysis was used to provide a sequential structure for the data analysis. An iterative approach was adopted in order to cover patient experiences. Familiarization with the range, depth and diversity of the data was performed by NA and WA. They agreed on an initial coding frame that was then applied to other transcripts, with the flexibility to enable other codes to be added. Key themes were developed and quotations were used to provide supporting evidence (Table 2). Themes were investigated until saturation was achieved. NVivo software (version 11.4.2) was used to manage the data.

\section{Results}

Six and 8 patients participated in the focus group and semistructured interviews ( 3 men and 5 women, including 1 man from the focus group). Participant age ranged between 26 and 71 years. Time since amputation ranged between 4 and 15 years, and levels of amputation varied among the participants ( 9 above knee, 3 below knee and 1 at ankle level). Six of the participants had bilateral above-knee amputation. Two main themes emerged from analysing the data: experiences and needs before amputation, and experiences in social and psychological adjustment after amputation (Table 3).

\section{Experiences and needs before amputation}

\section{Patient attitude}

Differences in reactions between those who were about to lose their limb at a young age and those who underwent amputation at an older age were found. A participant peacefully noted: "I told the doctor if this is (foot amputation) what you see as the best for me then...go for it! This is what God wants for me." (male, 67 years, focus group). Another participant added: "I might die at any time...losing a limb is not a big deal" (male, 73 years). A 26-year-old woman who had her leg amputated at the age of 12 years due to bone cancer explained: ".. when I heard 'cut her leg' I cried hysterically, because that means I will never be able to walk again."

Those who had their limbs amputated due to trauma and those who lost them due to vascular disease showed differences in their reaction to amputation. Participants who underwent surgery to restore the limb before amputation, were less frustrated. One participant explained: "I was glad that all the suffering will end..." (male, 29 years, focus group).

Consultation with religious men to lead prayers for amputees before their operations was common. Although they subsequently underwent amputation, 


\begin{tabular}{|c|c|c|}
\hline Primary codes & Categories & Themes \\
\hline $\begin{array}{l}\text { - Patients' attitude before amputation } \\
\text { - Family support before amputation } \\
\text { - Family attitude before amputation }\end{array}$ & $\begin{array}{l}\text { 1. Older patients tended to take a resilient attitude while } \\
\text { younger patients were more sensitive. } \\
\text { 2. Amputees who underwent restorative surgery were, } \\
\text { unlike those who lost their limb due to trauma, more } \\
\text { accepting of their situation. } \\
\text { 3. Consulting religious men for emotional support } \\
\text { 4. Need for support/empathy from the family }\end{array}$ & $\begin{array}{l}\text { Experiences and needs before } \\
\text { amputation }\end{array}$ \\
\hline $\begin{array}{l}\text { - Hopelessness and depression } \\
\text { - Spiritually related attitude } \\
\text { - } \text { Body image distress and self-esteem }\end{array}$ & $\begin{array}{l}\text { 1. Worrying of the unknown due to no knowledge about } \\
\text { amputation and its consequences made amputees } \\
\text { hopeless. } \\
\text { 2. Some younger participants experienced depression } \\
\text { 3. Limb loss was associated with sins } \\
\text { 4. Being more religious after amputation } \\
\text { 5. Body image consciousness when around spouse, } \\
\text { relatives and strangers causes depression } \\
\text { 6. Depending on others }\end{array}$ & $\begin{array}{l}\text { Experiences in social and } \\
\text { psychological adjustment after } \\
\text { amputation }\end{array}$ \\
\hline $\begin{array}{l}\text { - Family support } \\
\text { - } \text { Community support }\end{array}$ & $\begin{array}{l}\text { 1. Parents' and children's support } \\
\text { 2. Parents' close supervision } \\
\text { 3. Spouse support (a priori theme) } \\
\text { 4. Amputees did not want to be helped/ pitied in public. } \\
\text { 5. No work problem (a priori theme) } \\
\text { 6. Limitations to functional ability }\end{array}$ & Physical and psychological support \\
\hline
\end{tabular}

participants reported that they felt emotional and physical improvement afterwards. A 51-year-old woman said: "My daughter called a religious man who came to the hospital to read Quran on me and my affected leg...I definitely felt better, my leg started to be less painful. I was so comfortable...".

\section{Family support and attitude}

Participants' experience with family support before amputation varied. For example, a 48-year-old woman noted: "Everyone was crying... I was broken from the inside and seeing my kids crying was not helping at all. I had to find a way to calm them down, when I actually needed someone to calm me down...I went to my room and cried for a whole day and at the same time managing to hide the distress I was feeling..." In contrast, a 51-yeard-old woman explained that the balance between those who cried and those who were strong for her made the news of the amputation easier to accept: “I can't forget my dad's face... it was the first time I saw him crying... my daughter was strong and she was focusing on making me feel better..." Support and empathy were equally needed by participants before amputation. They felt important to their families and loved ones when they shared their emotions, and at the same time, they needed people who were strong and able to hide their emotions. This same patient added: "At that time, I have sensed how precious I am to my father."

\section{Experiences in social and psychological adjustment after amputation}

\section{Hopelessness and depression}

Having limited knowledge about amputation, in addition to not knowing someone who had been through the same situation, contributed to a state of hopelessness for the amputees. A 32-yeaar-old man noted: "I was wor- ried about my future. Being able to walk again has never crossed my mind." A 35-year-old man added: “...My friend told me that his cousin lost both her legs and she is able to walk now with prosthesis... I was so sad I couldn't even hold onto that hope." A 51-year-old woman said: "(a physiotherapist) here from the centre had arranged a meeting for me to see one of the prosthesis users ... I could not believe my eyes when I saw her (the prosthesis user)!" A 35-year-old man who had lost both limbs due to a car accident noted: "I woke up to find that both my legs were gone!... I was so angry I wished that I died before I got my legs amputated!"

Nervous breakdown and the development of clinical depression were mentioned by younger participants. "I was sad, crying whenever I'm alone..." (female, 26 years). "I was diagnosed with depression and I was using medications and consulting a psychiatrist for that." (male, 35 years)

\section{Spiritually related attitudes}

Psychological reaction to amputation was shaped by the patients' religious beliefs and spirituality. Losing a limb was associated with being a sinful person. "I can tell from their looks that they dislike me because they believe that I am not a good person and that's why I got punished by Allah (God)...but this is not true" (female, 51). The same participant added: "I used to constantly think...Why me? What did I do wrong to deserve that?" Reliance on and strengthening one's faith in God had a positive role in patients' psychological ability to adjust to life after amputation. Most participants stated being more religious after amputation. "I cannot say no...I pray more, and I hope more from God." (female, 36 years, focus group). According to the participants, being more spiritual was a source of hope and strength to be better able to cope with their physical and psychological health. "Every time 


\begin{tabular}{|c|c|}
\hline Themes & Subthemes \\
\hline $\begin{array}{l}\text { Experiences and needs before } \\
\text { amputation }\end{array}$ & $\begin{array}{l}\text { - Patients' attitude before } \\
\text { amputation } \\
\text { - Family support and attitude } \\
\text { before amputation }\end{array}$ \\
\hline $\begin{array}{l}\text { Experiences in social and } \\
\text { psychological adjustment after } \\
\text { amputation }\end{array}$ & $\begin{array}{l}\text { - Hopelessness and depression } \\
\text { - Spiritually related attitude } \\
\text { - Body image distress and self- } \\
\text { esteem }\end{array}$ \\
\hline $\begin{array}{l}\text { Physical and psychological } \\
\text { support }\end{array}$ & $\begin{array}{l}\text { - Family support } \\
\text { - Community support }\end{array}$ \\
\hline
\end{tabular}

I pray, I feel that Allah is hearing me, and he is supporting me. It makes me stronger... no, I still haven't reached the ultimate peacefulness though I did in others' eyes." (male, 32 years).

\section{Body image distress and self-esteem}

Being conscious about the changes in their appearances made most of the participants worry about being accepted by their community and by their families. A 35-year-old man who had both legs amputated 4 months after getting married noted: "I was worried that my wife would leave me as I don't look 'good' or... mutilated." A 51-year-old woman noted: "I did not like to go to malls or see strangers... people keep staring at me as if I were an alien!" Looking different from others may restrict amputees from moving forward with their lives. Although patients were able to assert their value, the struggle was deeper. "I admit that I wanted to quit studying at the university many times due to that feeling I had. Even if I tried to convince myself to live with my new different look peacefully and accept my new self...I am in a constant battle from the inside." (female, 26 years). A 51-yearold woman explained that it was the change in her body image that put her in a state of depression: "It was important for me to look normal. People talk and stare... it made me sad and not wanting to see anyone." Self-esteem was affected by amputees' body image and limited physical function. Participants reported being hesitant to go back to work after amputation due to their looks. One teacher noted: "I did not know how I could go back to work and meet my young students...I did not want to hear negative comments..." (female, 51 years). Another noted: "Feeling dependent after all the years of giving and providing for my family was difficult." (male, 61 years, focus group). In contrast, older participants expressed their surrender to their situation and tended to respond with words that reflected their gratification with what was destined to happen.

\section{Physical and psychological support}

Parents and children were mentioned by the participants as being their main source of support, even among married patients. One married participant stated: "My father was ready to do anything to help me through this... when I got home, I found my house to be fully equipped with handicapped facilities." (male, 35 years). Another single participant added: "My mum used to make sure that I was being entertained the whole time." (female, 36 years, focus group). Two young female participants reported needing support; however, too much of that may backfire on their ability to adjust mentally and physically to their new life. A participant who seemed to understand her mother's concerns noted: "My mum never left me alone! She used to come with me to school and then to the university every day the whole day to make sure that I don't need anything. It was tiring for her... and a bit limiting for me." (female, 26 years). Older patients, including those with spouses, tended to get their physical, psychological and financial support from their children. Spousal role in the physical support of amputation patients was also reported; however, this was not as significant as parental support. When asked about his wife's role as a supporter, a 35-year-old man reported: "My wife used to help my mother to take care of me when I most needed it."

It was important for the participants to feel comfortable in their environment. This included the workplace and other places that required regular visits, such as supermarkets and government departments. It was important for the participant to find wheelchair ramps, elevators, and disabled bathrooms in the places they visited. One participant stated:

"The community make us feel handicapped, but we are not!" (female, 36 years, focus group).

Since these facilities are not available everywhere in Saudi Arabia, people must ask, or be approached voluntarily by others for help, which may add to their psychological instability. A 26-year-old woman noted: "Every time someone helps with carrying the wheelchair, they ask about my leg and how I lost it...other passersby try to hear my story...it is annoying." Another patient added: "I remember an old lady saying, "you are young, you don't deserve this". I don't like the look of pity I get." (female, 36 years, focus group).

\section{Discussion}

The current study was conducted to explore the needs for better physical and psychological adjustment among lower limb amputees. Interviews indicated that patients needed a balanced environment for healthy expression of their emotions and that their physical and emotional symptoms could be alleviated by cultural and spiritual traditions. Furthermore, this study showed that in contrast to community support, family support was effective for adaptation and improvement of quality of life.

Having the opportunity to go through the decisionmaking process may lead to higher perceived control and improved adjustment (14). This study showed that previous distress of participants who underwent amputation after a series of reconstructive operations appeared to have more control over their emotions and needs. In contrast, those who underwent amputation due to trauma had greater difficulty in accepting their condition shortly after surgery. 
It could be argued that depressive reactions are a normal reaction to amputation rather than depression per se (1-5). Nevertheless, this study showed that depressive reactions could be minimized with patient education. Similar to previous studies (15), our results suggested that meeting with other amputees was the most useful source of information and support. This was possibly because emic sources of support and information were more trustworthy for patients.

Adaptation to body image could be used as a potential measure of psychological adjustment to amputation $(8,16)$. Participants in the present study showed selfconsciousness of their postamputation body image. In contrast to participants of previous studies $(17,18)$, younger participants showed limited acceptance to their new identity as amputees, and this affected their selfesteem around their families and loved ones.

Participants considered spirituality as a key element of the support system utilized in order to adjust to their new situation. In line with findings of other studies, we found that participants' spiritual beliefs stabilized their lives, provided meaning for the experience of disability, assisted them with coping, and enhanced their spiritual connection $(19,20)$. Simultaneously, some amputees believed that going through amputation was a punishment from God for their sins; the latter belief made them isolate themselves from the community. Another study on families of intensive care patients in Saudi Arabia found that families believed that illness was a test from God, rather than a punishment (19).

Family support is the main source of psychological strength among amputees and patients with chronic disease in general (21-24). This is the first study to explore patient needs from their family before amputation. Participants reported needing a balanced reaction to enable them to feel strong and express their emotions simultaneously. Potential amputees may suppress their true feelings if their families overlook the support they could provide.
In contrast with other research conducted in similar cultural settings, this study found that parents and/or children, were the main source of support for lower-limb amputees (25-27). Participants in our study reinforced the role of their parents, or their children for older patients, in improving physical and emotional adjustment. Patients did acknowledge their spouses' role, but seemed to take this for granted.

Our study explained that local cultural and social context factors may make amputees feel handicapped. It has been noted in a qualitative study that people develop their identity and interpretation of their look from other peoples' perspective (28). In concordance, participants in the current study did not like to be pitied or helped by others when logistics were lacking.

The experiences of disadvantaged patients who did not utilize rehabilitation services could be different from those in the present study. Future research should look at the experiences of less-advantaged lower limb amputees who have poor access to rehabilitation services. The role of spouses and religious/traditional healers in the physical and psychological adjustment could be further explored.

\section{Conclusions}

A range of unmet needs, which involved family, community and religious support, was identified among lower-limb amputees. This study calls upon policy-makers to participate in reducing social and psychological implications of amputation as a disability, by empowering amputees to acquire their right of independence and social inclusion by providing all the necessary logistics. Healthcare professionals should pay more attention to patient needs and support systems by involving families and religious healers in amputees' treatment plans, in addition to introducing success stories and life examples to alleviate the emotionally destructive news of amputation.

\section{Acknowledgement}

The authors are grateful to the Deanship of Scientific Research, King Saud University, for funding through the Vice Deanship of Scientific Research Chairs. The authors are thankful to Professor Abdulrahman Abouammoh for his support and gratefully acknowledge the patients who participated in this study.

Funding: None.

Competing interests: None declared.

\section{Expériences et besoins des patients amputés d'un membre inférieur en Arabie saoudite : étude qualitative}

\section{Résumé}

Contexte : L'effet de l'amputation sur le bien-être social et psychologique des patients a été établi. Cependant, les expériences et les besoins des personnes amputées pour le processus d'adaptation varient selon les individus et les cultures.

Objectifs : La présente étude visait à examiner les expériences et les besoins des sujets amputés des membres inférieurs en matière d'adaptation sociale et psychologique en Arabie saoudite, selon leur propre perspective. 
Méthodes : Treize patients amputés d'un membre inférieur (âge moyen de 47 ans) ont été recrutés dans un grand centre de réadaptation en Arabie saoudite pour participer à des entretiens. Un groupe de discussion thématique avec six patients a été suivi d'entretiens individuels et semi-structurés avec huit patients (dont un ayant participé au groupe de discussion thématique) entre novembre 2017 et mars 2018.

Résultats : Les besoins et les réactions des patients avant et après l'amputation étaient déterminés par le système de soutien environnant. Le désespoir et la dépression, la détresse liée à l'image corporelle, l'attitude religieuse et le soutien familial et communautaire ont tous contribué à façonner l'expérience globale du patient, y compris l'adaptation psychologique et physique.

Conclusions : Faciliter la réintégration des patients amputés des membres inférieurs dans leur communauté, ainsi que fournir le système de soutien nécessaire, est crucial pour assurer un processus d'adaptation favorisant la santé à ces derniers.

$$
\text { توزارب وا بواحتياجات مرضى وسيم الدبيان، رباب أبو زيد الأطر اف السفلية في المملكة العربية السعودية: دراسة نوعية }
$$

الخلفية: ثُبت أن البتر يؤثر على السلامة الاجتهاعية والنفسية للمرضى، غير أن تجارب مرضى البتر واحتياجاتهم من أجل عملية التكيف تختلف من ثقافة إلى أخرى ومن فرد إلى آخر .

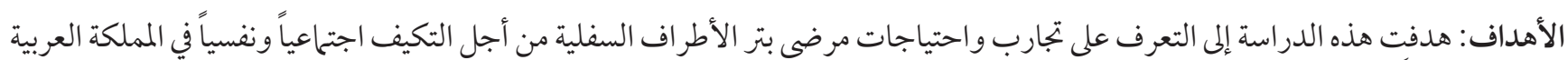

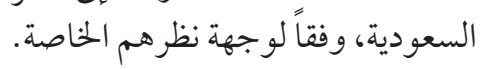

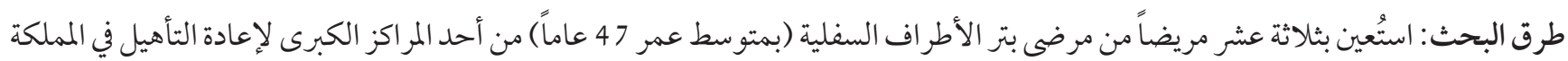

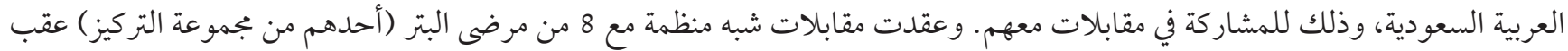

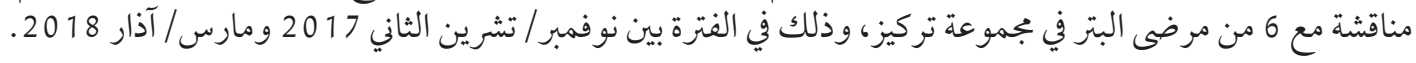
النتائج: تحكم نظام الدعم المحيط في احتياجات المرضى وردود أفعالمم قبل البتر وبعده. وقد ساهم كل من اليأس والاكتئاب و الشعور بالضيق من صورة الجسم و الموقف الديني و الدعم الأسري و المجتمعي في في تشكيل تجربة المرضى بشكل عام، ويشمل ذلك عملية التكيف النفسي و البدني. الاستنتاجات: من الضروري تيسير إعادة دمج مرضى بتر الأطر اف السفلية في بجتمعاتهم وتو فير نظام الدعم المطلوب لهم لضمان تحقق عملية تكيف مرضى البتر بصورة صحية.

\section{References}

1. Mckechnie PS and John A. Anxiety and depression following traumatic limb amputation: a systematic review. Injury. 2014 Dec; 45(12):1859-66. http://dx.doi.org/10.1016/j.injury.2014.09.015 PMID:25294119

2. Belon HP and Vigod DF. Emotional adaptation to limb loss. Phys Med Rehabil Clin N Am. 2014 Feb; 25(1):53-74. http://dx.doi. org/10.1016/j.pmr.2013.09.010 PMID:24287240

3. Bragaru M. Van Wilgen CP, Geertze J.H, Ruij SG, Dijkstra PU, Dekker R. Barriers and facilitators of participation in sports: a qualitative study on Dutch individuals with lower limb amputation. PloS One. 2013; 8(3):e59881. http://dx.doi.org/10.1371/journal. pone.0059881 PMID:23533655

4. Horgan O, MacLachlan M. Psychosocial adjustment to lower-limb amputation: a review. Disabil Rehabil. 2004 Jul 22-Aug 5; 26(14-15):837-50. http://dx.doi.org/10.1080/09638280410001708869 PMID:15497913

5. Durmus D, Safaz I, Adıgüzel E, Uran A, Sarısoy G, Goktepe AS, et al. The relationship between prosthesis use, phantom pain and psychiatric symptoms in male traumatic limb amputees. Compr Psychiatry.2015 May;59:45-53. http://dx.doi.org/10.1016/j. comppsych.2014.10.018 PMID:25764906

6. Furst L, Humphrey M. Coping with the loss of a leg. Prosthet Orthot Int. 1983;7(1):152-6.

7. Murray CD, Forshaw MJ. The experience of amputation and prosthesis use for adults: a metasynthesis. Disabil Rehabil.2013 Jul;35(14):1133-42. http://dx.doi.org/10.3109/09638288.2012.723790 PMID:23033871

8. Holzer LA, Sevelda F, Fraberger G, Bluder O, Kickinger W, Holzer G. Body image and self-esteem in lower-limb amputees. PLoS One. 2014 Mar 24;9(3):e92943. http://dx.doi.org/10.1371/journal.pone.0092943 PMID:24663958

9. Lupton, D. Medicine as culture: illness, disease and the body. Sage; 2012

10. Statistical year book. Ministry of Health, Saudi Arabia; 2018 (https://www.moh.gov.sa/en/Ministry/Statistics/book/Pages/default.aspx, accessed 4 September 2020) 
11. AlSofyani MA, AlHarthi AS, Farahat FM, Abuznadah WT. Impact of rehabilitation programs on dependency and functional performance of patients with major lower limb amputations: a retrospective chart review in western Saudi Arabia. Saudi Med J. 2016 Oct;37(10):1109-13. http://dx.doi.org/10.15537/smj.2016.10.16033 PMID:27652362

12. Al-Thani H, Sathian B, El-Menyar A. Assessment of healthcare costs of amputation and prosthesis for upper and lower extremities in a Qatari healthcare institution: a retrospective cohort study. BMJ Open. 2019;9:e024963. http://dx.doi.org/10.1136/bmjopen-2018-024963

13. Senra H, Oliveira RA, Leal I, Vieira C. Beyond the body image: a qualitative study on how adults experience lower limb amputation. Clin Rehabil 2012 Feb;26(2):180-91. http://dx.doi.org/10.1177/0269215511410731 PMID:21908476

14. Ogden, J. Health psychology a textbook. Open University Press; 2012.

15. Hamill R, Carson S, Dorahy M. Experiences of psychosocial adjustment within 18 months of amputation: an interpretative phenomenological analysis. Disabil Rehabil. 2010;32(9):729-40. http://dx.doi.org/10.3109/09638280903295417 PMID:20302441

16. Cho H, MacLachlan M, Clarke M, Mannan H. Accessible home environments for people with functional limitations: a systematic review. Int J Environ Res Public Health. 2016 Aug 17;13(8):826. http://dx.doi.org/10.3390/ijerph13080826 PMID:27548194

17. Akarsu S, Tekin L, Safaz I, Göktepe AS, Yazıcıoğlu K. Quality of life and functionality after lower limb amputations: comparison between uni- vs. bilateral amputee patients. Prosthet Orthot Int. 2013 Feb;37(1):9-13. http://dx.doi.org/10.1177/0309364612438795 PMID:22833517

18. Weiss G. Body images: embodiment as intercorporeality. London: Routledge; 2013

19. Al-Mutair AS, Plummer V, Clerehan R, O'brien A. Needs and experiences of intensive care patients' families: a Saudi qualitative study. Nurs Crit Care. 2014 May;19(3):135-44. http://dx.doi.org/10.1111/nicc.12040 PMID:24118629

20. Treloar LL. Disability, spiritual beliefs and the church: the experiences of adults with disabilities and family members. J Adv Nurs. 2002 Dec 40(5):594-603. http://dx.doi.org/10.1046/j.1365-2648.2002.02417.x PMID:12437609

21. Valizadeh S, Dadkhah B, Mohammadi E, Hassankhani,H. The perception of trauma patients from social support in adjustment to lower-limb amputation: A qualitative study. Indian journal of palliative care. 2014 Sep;20(3):229-38. http://dx.doi. org/10.4103/0973-1075.138401 PMID:25191013

22. Oztunc G, Yesil P, Paydas S, Erdogan S. Social support and hopelessness in patients with breast cancer. Asian Pac J Cancer Prev. 2013;14(1):571-8. PMID:23534797

23. Abdullah-zadeh F, Agahosseini S, Asvadi-Kermani I, Rahmani A. Hope in Iranian cancer patients. Iranian J Nurs Midwifery Res. 2011 Fall;16(4):288-91. PMID:23450037

24. Li QP. Mak YW, Loke AY. Spouses' experience of caregiving for cancer patients: a literature review. Int Nurs Rev. 2013 Jun;6o(2):178-87. http://dx.doi.org/10.1111/inr.12000 PMID:23692000

25. Delgado-Guay MO, Parsons HA, Hui D, Cruz MGDL, Thorney S, Bruera E. Spirituality, religiosity, and spiritual pain among caregivers of patients with advanced cancer. Am J Hosp Palliat Care. 2013 Aug;30(5):455-61. http://dx.doi. org/10.1177/1049909112458030 PMID:22952129

26. Wen KY, Fang CY, Ma GX. Breast cancer experience and survivorship among Asian Americans: a systematic review. J Cancer Surviv. 2014 Mar;8(1):94-107. http://dx.doi.org/10.1007/s11764-013-0320-8 PMID:24214498

27. Jassim GA, Whitford DL. Understanding the experiences and quality of life issues of Bahraini women with breast cancer. Soc Sci Med. 2014 Apr;107:189-95. http://dx.doi.org/10.1016/j.socscimed.2014.01.031 PMID:24631996

28. Monteleone R, Forrester-Jones R. 'Disability means, um, dysfunctioning people': A qualitative analysis of the meaning and experience of disability among adults with intellectual disabilities. J Appl Res Intellect Disabil. 2017 Mar;30(2):301-15. http://dx.doi. org/10.1111/jar.12240 PMID:26834036 